\title{
Review
}

\section{Activity-Dependent Inhibitory Synaptogenesis in Cerebellar Cultures}

\author{
Fredrick John Seil* \\ Department of Neurology, Oregon Health \& Science University, Portland, OR, USA
}

\begin{abstract}
Inhibitory synapses on Purkinje cell somata in organotypic cerebellar cultures derived from newborn mice were increased after chronic exposure post explantation to agents that enhance neuronal activity. Inhibitory synaptogenesis was reduced in similar cultures after continuous blockade of spontaneous neuronal discharges. By contrast, excitatory synapses developed fully in the absence of neuronal activity. The reduction of inhibitory synaptogenesis was prevented by the simultaneous application of activity blocking agents and neurotrophins BDNF or NT-4, which are TrkB receptor ligands, but not with NT-3, a TrkC receptor ligand. The effect of endogenous neurotrophins was evaluated by continuously exposing cerebellar cultures to antibodies to BDNF and NT-4, which caused a significant reduction in the development of inhibitory Purkinje cell axosomatic synapses. These combined results indicated a role for TrkB receptors in activity-dependent inhibitory synaptogenesis. This concept was supported by the promotion of inhibitory synaptogenesis by specific antibody activation of TrkB receptors.
\end{abstract}

Keywords: Purkinje cells, neuronal activity, synapses, neurotrophins, TrkB receptors

\section{INTRODUCTION}

Neuronal activity is critical for development of some parts of the nervous system, including visual [1-5], auditory [6], olfactory [7] and somatosensory [8] systems. Data derived from both animal studies [9-13] and studies with nervous system cultures [14-20] indicated that neuronal activity is necessary for the development of the full complement of inhibitory synapses. By contrast, an induced increase in neuronal activity both accelerated and augmented inhibitory synapse formation [21-23].

Neurotrophins appear to have essential roles in activity-dependent plastic changes [24-26]. The neurotrophin family members include nerve growth factor (NGF), brain-derived neurotrophic factor (BDNF), neurotrophin-3 (NT-3) and neurotrophin-4

\footnotetext{
${ }^{*}$ Correspondence to: Fredrick John Seil, 1 Twain Avenue, Berkeley, CA 94708, USA. Tel.: +1 510841 2398; E-mail: seilf@comcast.net.
}

(NT-4). The high affinity receptor tyrosine kinases with which they bind are TrkA for NGF, TrkB for BDNF and NT-4 and TrkC for NT-3 [27-29]. In a study in which neuronal activity was blocked in dissociated visual cortex cultures containing GABAergic interneurons and target pyramidal cells, Rutherford et al. [30] found that the percentage of GABA-immunopositive neurons was reduced and that pyramidal cell discharge rates were increased. The effects of activity blockade were prevented by simultaneous exposure of the cultures to BDNF, but not to NGF or NT-3 (NT-4 was not tested). The authors concluded that activity regulates cortical inhibition by regulation of BDNF.

In this brief review I will describe studies from my laboratory of the effects of both enhancement and blockade of neuronal activity in organotypic cerebellar cultures derived from newborn mice, and of the consequences of simultaneous application of activity blocking agents and neurotrophins. More extensive reviews have been published [31, 32]. 


\section{THE MODEL}

The organotypic cerebellar culture model system was chosen because the contained cortical neuronal types and their functions are known, allowing quantitative studies of synaptogenesis and correlation with electrophysiological data. Structural and functional roles of cortical neurons of the rodent cerebellum in vivo had been well defined [33, 34]. In a series of studies we determined that the same structural and functional relationships developed in organotypic cerebellar cultures [35-39]. As such cultures were derived from newborn mice at a time when there was very little development of cortical synapses, most of the cortical synaptogenesis occurred in vitro.

The cultures were prepared by trimming the lateral tips of the isolated cerebella and then dividing each cerebellum into seven parasagittaly oriented slices. Each explant was placed onto a collagen coated coverslip with a drop of nutrient medium and incorporated into a Maximow chamber [40, 41]. The standard nutrient medium, which was replaced twice weekly, consisted of two parts $3 \mathrm{IU} / \mathrm{ml}$ low-zinc insulin, one part $20 \%$ dextrose, eight parts Eagle's minimum essential medium with Hanks' base and added L-glutamine, seven parts Simms' X-7 balanced salt solution (BSS) with incorporated HEPES buffer (pH 7.4) to make its concentration $10^{-2} \mathrm{M}$ in the fully constituted medium, and twelve parts fetal calf serum.

Definable cortical and subcortical regions with myelinated axons in between were evident by two weeks in vitro. All of the major cortical neuronal types were represented, including Purkinje, granule, basket, stellate and Golgi cells. Their afferent and efferent projections are diagrammed in Fig. 1. Purkinje cells, which are inhibitory, are the only neurons which project their axons beyond the cerebellar cortex. In addition, they project axon collaterals to all other cortical neurons, including other Purkinje cells. Granule cells are the only excitatory cortical neurons, and they project axons as bundles of parallel fibers to the dendrites of all other cortical neurons and form numerous synapses with Purkinje cell dendritic spines. The remaining cortical neurons are inhibitory interneurons. Basket cell axons innervate Purkinje cell somata and proximal dendrites, stellate cells project to more distal portions of Purkinje cell dendrites and Golgi cells send axons to form synapses with granule cell dendrites. All of these synaptic relationships were present in cerebellar cultures. Absent from these cultures since they were isolated cerebella

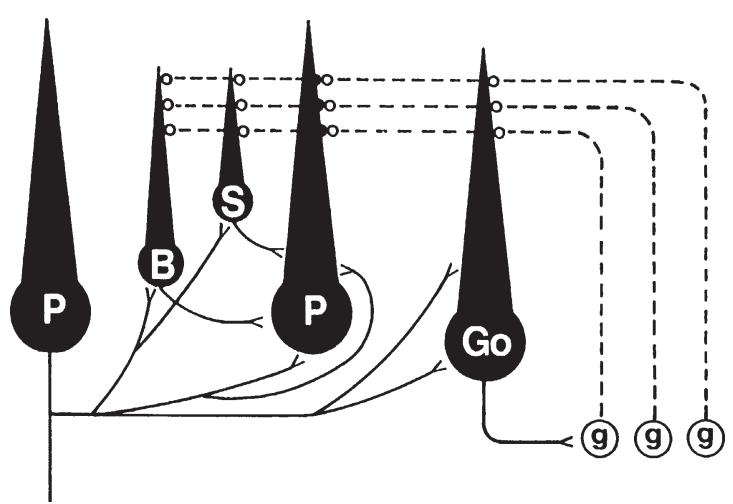

Fig. 1. Circuit diagram of the major cerebellar cortical neurons and their projections. Not shown are the extracellular afferents, as they are absent in isolated organotypic cerebellar cultures. Inhibitory projections, shown as solid black lines, from Purkinje cells (P) are illustrated on the Purkinje cell on the left side of the diagram, while projections to Purkinje cells are shown on the Purkinje cell in the center. Purkinje cells are the only cortical neurons that project axons from the cortex. Their axon collaterals project to all other inhibitory cortical neurons, including other Purkinje cells. Granule cells $(\mathrm{g})$ are the only excitatory neurons in the cerebellar cortex and their projections, the parallel fibers (shown as dashed lines), project to the dendrites of all other cortical neurons. Basket cell (B) axons project to Purkinje cell somata and proximal dendrites, while stellate cell (S) axons innervate more distal portions of Purkinje cell dendrites. Golgi cells $(G)$ project multibranched axons to the dendrites of granule cells. From reference 31 with permission.

were extracerebellar afferents, including mossy and climbing fibers.

A key anatomical feature of the cultures with regard to the studies to be described are the Purkinje cell axosomatic synapses. These were derived from two sources, namely basket cell axons and Purkinje cell recurrent axon collaterals, present in a 1:1 ratio. The average number of axosomatic synapse profiles to Purkinje cell profiles in untreated control cultures was 2.20 (Table 1). This system provided an easily measurable and quantifiable sample of the population of inhibitory synapses, allowing for correlation of morphological with physiological data.

\section{EFFECTS OF ACTIVITY ENHANCING AGENTS}

For purposes of electrophysiological recording, cerebellar cultures attached to their collagen coated coverslips were removed from the Maximow assemblies and transferred to a chamber mounted on the stage of an inverted microscope. The nutrient medium was removed and replaced with BSS additionally buffered with $1.5 \times 10^{-2} \mathrm{M}$ HEPES. Immediately present extracellularly recorded spontaneous cortical 
Table 1

Ratio of axosomatic synapse profiles to Purkinje cell somatic profiles in control and experimental cerebellar cultures

\begin{tabular}{|c|c|c|c|c|}
\hline Cultures & $\begin{array}{l}\text { No. of cell } \\
\text { profiles }\end{array}$ & $\begin{array}{l}\text { No. of synapse } \\
\text { profiles }\end{array}$ & $\begin{array}{l}\text { Mean ratio of synapse } \\
\text { to cell profiles } \pm \text { SEM }\end{array}$ & Source \\
\hline Control & 78 & 168 & $2.15 \pm 0.15$ & 42 \\
\hline $\operatorname{PTX}\left(2 \times 10^{-4} \mathrm{M}\right)$ & 58 & 279 & $4.81 \pm 0.35$ & \\
\hline Bicuculline & 79 & 318 & $4.03 \pm 0.22$ & \\
\hline Control & 23 & 44 & $1.91 \pm 0.34$ & 43 \\
\hline $\mathrm{Mg}^{2+} / \mathrm{TTX}$ & 45 & 43 & $0.96 \pm 0.15$ & \\
\hline Control & 103 & 228 & $2.21 \pm 0.13$ & 48,49 \\
\hline $\mathrm{Mg}^{2+} / \mathrm{TTX}$ & 102 & 127 & $1.25 \pm 0.10$ & \\
\hline $\mathrm{Mg}^{2+} / \mathrm{TTX} / \mathrm{BDNF}$ & 102 & 235 & $2.30 \pm 0.14^{*}$ & \\
\hline Control & 100 & 200 & $2.00 \pm 0.14$ & 48,49 \\
\hline $\mathrm{Mg}^{2+} / \mathrm{TTX}$ & 101 & 104 & $\mathbf{1 . 0 3} \pm \mathbf{0 . 1 1}$ & \\
\hline $\mathrm{Mg}^{2+} / \mathrm{TTX} / \mathrm{NT}-3$ & 103 & 107 & $\mathbf{1 . 0 4} \pm \mathbf{0 . 1 1}$ & \\
\hline Control & 100 & 215 & $2.15 \pm 0.13$ & 48,49 \\
\hline $\mathrm{Mg}^{2+} / \mathrm{TTX}$ & 100 & 121 & $1.21 \pm 0.11$ & \\
\hline $\mathrm{Mg}^{2+} / \mathrm{TTX} / \mathrm{NT}-4$ & 104 & 209 & $2.01 \pm 0.12 *$ & \\
\hline Control & 93 & 241 & $2.59 \pm 0.18$ & 49 \\
\hline $\begin{array}{l}\alpha \mathrm{BDNF} / \alpha \mathrm{NT}-4 \\
(50 \mu \mathrm{g} / \mathrm{ml} \text { each })\end{array}$ & 92 & 124 & $1.35 \pm 0.11$ & \\
\hline Control & 80 & 183 & $2.29 \pm 0.15$ & 49 \\
\hline $\operatorname{PTX}\left(10^{-4} \mathrm{M}\right)$ & 80 & 277 & $3.46 \pm 0.24$ & \\
\hline $\begin{array}{l}\text { PTX/ } \alpha \text { BDNF } / \alpha \text { NT- } 4 \\
(\alpha: 50 \mu \mathrm{g} / \mathrm{ml} \text { each })\end{array}$ & 82 & 204 & $2.49 \pm 0.17 *$ & \\
\hline $\begin{array}{l}\text { PTX/ } \alpha \text { BDNF/ } \alpha \text { NT- } 4 \\
(\alpha: 100 \mu \mathrm{g} / \mathrm{ml} \text { each })\end{array}$ & 80 & 112 & $1.40 \pm 0.15$ & \\
\hline Control & 77 & 157 & $2.04 \pm 0.14$ & 56 \\
\hline$\alpha \operatorname{TrkB}$ & 80 & 261 & $3.26 \pm 0.19$ & \\
\hline$\alpha \operatorname{TrkC}$ & 77 & 158 & $2.05 \pm 0.17$ & \\
\hline
\end{tabular}

SEM, standard error of the mean; PTX, picrotoxin; TTX, tetrodotoxin: BDNF, brain-derived neurotrophic factor; NT-3, neurotrophin-3; NT-4, neurotrophin-4; $\alpha$, antibody directed to. Source numbers refer to the reference numbers from which the data were derived. Values for mean ratios of synapse to cell profiles that were significantly different from those of untreated control cultures are indicated in bold type. Asterisks indicate values not significantly different from controls because of an experimental manipulation. Statistical significance was determined by Student's paired $t$ - test for data from references 42 and 43, and by one-way ANOVA followed by the Tukey HSD multiple comparisons test for data from references 48, 49 and 56. Table modified from reference 31 with permission.

spike discharges, primarily of Purkinje cell origin, were abundantly present in mature cerebellar cultures. Cortical surface electrical stimulation was followed by brief periods of inhibition of cortical activity.

Cortical discharge rates in mature cultures were markedly increased by acute application of antiGABA agents, either picrotoxin (PTX), which is thought to uncouple the $\mathrm{GABA}_{\mathrm{A}}$ receptor site from the chloride channel, thus preventing the latter from opening, or bicuculline, which competitively blocks the $\mathrm{GABA}_{\mathrm{A}}$ receptor [42]. Upon incorporation of $2 \times 10^{-4} \mathrm{M}$ of either PTX or bicuculline in the culture nutrient medium at the time of explantation and recording cortical electrical activity after 3 days in vitro (DIV), low amplitude spike discharges were considerably more frequent than in control cultures. After continuous exposure to PTX or bicuculline for 13-16 DIV, however, cortical spontaneous discharge rates were reduced to about half of that for control cultures maintained in standard nutrient medium for the same period of time. Cortical electrical stimulation of cultures continuously exposed to anti-GABA agents resulted in prolonged inhibition of cortical discharges. Inhibition in response to stimulation also appeared earlier in PTX or bicuculline treated cultures, being consistently present after $8 \mathrm{DIV}$, as opposed to 12 DIV for control cultures.

Correlative structural differences between cultures exposed to anti-GABA agents and controls were evident on electron microscopic examination after 14-16 DIV. Purkinje cells in the former had twice as many inhibitory axosomatic synapses as in the latter. As shown in Table 1, the mean ratio of somatic synapse profiles to Purkinje cell soma profiles was 2.15 in the control group, 4.81 in cultures exposed to PTX and 4.03 in bicuculline treated explants. With regard to the specific identities of the synapses, both basket cell and Purkinje cell recurrent axon collateral presynaptic terminals were represented, but in a $2: 1$ 
ratio, as opposed to a 1:1 ratio in control cultures, indicating that primarily basket cells sprouted additional axon terminals to provide increased inhibition in response to enhanced neuronal activity.

\section{EFFECTS OF ACTIVITY BLOCKING AGENTS}

Cerebellar cultures maintained in the absence of neuronal activity were similarly studied [43]. Purkinje cells were silenced by blocking somatic $\mathrm{Na}^{+}$ spikes with $10^{-8} \mathrm{M}$ of the $\mathrm{Na}^{+}$channel blocker, tetrodotoxin (TTX), and dendritic $\mathrm{Ca}^{2+}$ spikes were blocked with $11.1 \mathrm{mM}$ of the $\mathrm{Ca}^{2+}$ antagonist, $\mathrm{Mg}^{2+}$ incorporated into the nutrient medium. Upon electrophysiological recording after 13-16 DIV, control explants were immediately active after application of the recording medium. Activity-blocked cultures, however, were silent for about 10 minutes after transfer to the recording medium. Subsequently cortical discharges appeared at a slow rate, but progressively increased until they became hyperactive, including bursts of rapid spikes, by 30-40 minutes after transfer. This hyperactivity then persisted for the duration of the recording sessions, up to 2 hours.

Ultrastructural studies again correlated with the physiological findings in that activity-blocked cultures had half the number of inhibitory Purkinje cell axosomatic synapses as control cultures. The mean ratio of somatic synapse profiles to Purkinje cell soma profiles in this group of control cultures was 1.91 compared with 0.96 in cultures maintained in activity blocking agents (Table 1). The ratio of basket cell axosomatic synapses to Purkinje cell recurrent axon collateral synapses in activity-blocked cultures was $1: 1$, indicating that both classes of inhibitory synapses were equally affected. Electron microscopic examination of the cortical neuropil in both treated and control cultures revealed that there was no reduction of excitatory synapses in activity-blocked cultures. This result was consistent with those of earlier studies of excitatory synaptogenesis in organotypic cultures subjected to blockade of neuronal activity $[44,45]$.

\section{NEUROTROPHINS AND INHIBITORY SYNAPTOGENESIS}

As Rutherford et al. [30] found that effects of activity blockade on inhibitory synaptogenesis in dissociated visual cortex cultures were prevented by simultaneous exposure to exogenously applied BDNF, but not to NGF or NT-3, we pursued similar studies in our organotypic cerebellar culture system. Because TrkA, the high affinity receptor for NGF, was expressed only transiently on Purkinje cells during development [46, 47], we focused our studies on the other neurotrophins, BDNF, NT-3 and NT-4 [48, 49]. These neurotrophins were individually applied to cerebellar cultures at concentrations of $25 \mathrm{ng} / \mathrm{ml}$ medium along with activity blocking agents, TTX and elevated levels of $\mathrm{Mg}^{2+}$, at explantation and continuously thereafter for 15 DIV. Control cultures consisted of explants maintained in standard nutrient medium and cultures exposed to activity blocking agents without neurotrophins.

Following transfer to a recording medium after 15 DIV, all cultures that had been exposed to activityblocking agents were silent for the first 10 minutes after transfer. Subsequent to recovery from activity blockade, cultures exposed to activity blocking agents plus either BDNF or NT-4 had spontaneous cortical discharge rates similar to untreated control cultures. Cultures maintained with activity blocking agents plus NT-3 and those maintained with activity blocking agents alone developed sustained hyperactive cortical discharges 30-40 minutes after release from activity blockade.

Electron microscopic examination of the various culture groups after 15 DIV revealed that cultures exposed to activity blocking agents alone or activity blocking agents plus NT-3 had reduced numbers of Purkinje cell axosomatic synapses, while cultures treated with activity blocking agents plus either BDNF or NT-4 had Purkinje cell axosomatic synapse counts comparable to those of untreated control cultures (Table 1). The anatomical results correlated with those of the functional studies, and supported the concept that TrkB receptor ligands, BDNF and NT-4, but not the TrkC receptor ligand, NT-3, promoted inhibitory synaptogenesis in the absence of neuronal activity.

The role of endogenous neurotrophins, which appeared to be synthesized and released in an activitydependent manner [24, 50, 51], was investigated by continuously exposing cerebellar cultures to antibodies to BDNF and NT-4 from explantation to 15 DIV [49]. Cultures treated with a combination of these antibodies at a concentration of $50 \mu \mathrm{g} / \mathrm{ml}$ nutrient medium each developed only half of the number of Purkinje cell axosomatic synapses as untreated control cultures (Table 1). The effect was equivalent to blockade of neuronal activity. 
When neuronal activity was augmented by continuous exposure of cultures to $10^{-4} \mathrm{M}$ PTX, which increased the number of Purkinje cell axosomatic synapses by $50 \%$ (Table 1), simultaneous exposure to the same concentration of antibodies to BDNF and NT-4 resulted in a Purkinje cell axosomatic synapse count similar to that of control cultures. Doubling the concentration of the antibodies reduced the axosomatic synapse count further to about half of the control value (Table 1).

\section{TrkB RECEPTOR ACTIVATION}

Since the studies described thus far pointed to a role for the TrkB receptor in activity-dependent inhibitory synaptogenesis, we pursued the possibility of specific antibody activation of the TrkB receptor to determine if such activation might promote inhibitory synaptogenesis. Specific antibody activation of TrkA and ephrin receptors had been described, and the effects produced were similar to the biological effects of the receptor ligands [52-55]. Cerebellar cultures were continuously exposed to antibodies $(1 \mu \mathrm{g} / \mathrm{ml}$ nutrient medium each) to the extracellular domains of TrkB and TrkC for 15 DIV [56]. On subsequent ultrastructural examination, cultures exposed to antibody to TrkB had an approximately 60\% increase in Purkinje cell axosomatic synapses above control values, while there was no increase of Purkinje cell axosomatic synapses in cultures exposed to antibody to TrkC. As shown in Table 1, the mean ratio of synapse to cell profiles in cultures treated with anti-TrkB antibody was 3.26, which compared to 2.04 for control cultures and 2.05 for explants exposed to anti-TrkC antibody. The increase in inhibitory synaptogenesis by specific antibody activation of the TrkB receptor was similar to that induced by continuous exposure of cerebellar cultures to a high dose ( $100 \mathrm{ng} / \mathrm{ml}$ medium) of BDNF [31]. These results included the TrkB receptor as being among those producing ligand agonistic effects by specific antibody activation and supported the concept that signaling for activity-dependent inhibitory synaptogenesis is via the TrkB receptor.

\section{DISCUSSION AND CONCLUSIONS}

In these studies we have shown that increased neuronal activity induced by exposure to anti-GABA agents in a cerebellar culture model system during development results in increased inhibitory synaptogenesis, as defined by quantitative morphological criteria, and a proportional decrease in spontaneous cortical electrical discharges. These results were in agreement with those of previous studies $(20,21,23)$ and the morphological data confirmed the increase in inhibitory synapses. Blockade of neuronal activity in cerebellar cultures during development by application of TTX and elevated levels of $\mathrm{Mg}^{2+}$ had the opposite effect, as inhibitory synaptogenesis was reduced, again by quantitative morphological criteria, and cultures recovering after release from blockade of neuronal activity discharged hyperactively throughout the subsequent recording period. These findings were consistent with those of earlier work $(1-20,22)$ and the quantitative morphological data supported the notion of a selective failure of development of the full complement of inhibitory synapses in the absence of neuronal activity.

Following upon a study (30) in which the effects of activity blockade (a reduced percentage of GABAimmunopositive neurons and increased pyramidal cell discharge rates) in dissociated visual cortex cultures were prevented by simultaneous exposure to BDNF, but not to NGF or NT-3, we applied neurotrophins BDNF, NT-3 and NT-4 exogenously to cerebellar cultures during development under activity blockade $(48,49)$. The TrkB receptor ligands, BDNF and NT-4, promoted full development of inhibitory synapses during activity blockade, as determined by quantitative morphological criteria and normal spontaneous cortical discharge rates after release from blockade, but cultures exposed to the TrkC receptor ligand, NT-3, did not escape the consequences of an absence neuronal activity. As these results pointed to TrkB receptor ligands as promoters of activitydependent inhibitory synaptogenesis, we explored properties of endogenous BDNF and NT-4 by exposing cerebellar cultures to antibodies to these ligands during development (49). The effects were similar to those of activity blockade, with a reduced development of Purkinje cell axosomatic synapses to approximately half the control level. Similar antibody exposure of cultures simultaneously treated with PTX prevented increased inhibitory synaptogenesis, as seen with cultures exposed only to PTX (42). This result suggested that increased inhibitory synaptogenesis as a consequence of increased neuronal activity is at least partially attributable to elevated levels of endogenously secreted TrkB receptor ligands. Finally we demonstrated that direct antibody activation of the TrkB receptor produced biological effects like those of application of TrkB receptor ligands (56), similar to that of previously reported effects of 
direct antibody activation of TrkA and ephrin receptors (52-55). This result indicated that signaling for activity-dependent inhibitory synaptogenesis is via the TrkB receptor.

Conclusions to be drawn from these studies are: 1) neuronal activity is necessary for the complete development of inhibitory circuitry, 2) TrkB receptor ligands have a role in activity-dependent inhibitory synaptogenesis and 3) signaling for activity-dependent inhibitory synaptogenesis is via the TrkB receptor. Excitatory synapses, on the other hand, develop fully in the absence of neuronal activity (43-45).

There are at least three ways of promoting inhibitory synaptogenesis, including 1) application of exogenous TrkB receptor ligands, 2) increasing release of endogenous TrkB receptor ligands by activity, such as exercise [57], and 3) activating TrkB receptors by binding with specific antibody. The possible clinical significance of these studies relates to the necessity for restoration of inhibitory circuitry after insults such as trauma or stroke, in which the balance between excitatory and inhibitory elements may be disrupted. Activity is known to promote functional recovery in both experimental and clinical conditions [57-59]. That the effects of activity appear to be mediated through TrkB receptor ligands may have therapeutic implications. It has been shown in animal studies that infusion of BDNF or measures that enhance BDNF after appropriate intervals following induction of experimental stroke improve functional recovery [60-62]. Future developments may advance such measures to the treatment of human neurological disorders.

\section{ACKNOWLEDGMENTS}

I would like to acknowledge the contributions of my collaborators in these studies, whose names appear as co-authors in the References. Work from my laboratory was supported by the Medical Research Service of the US Department of Veterans Affairs and by the National Institutes of Health.

\section{CONFLICT OF INTEREST}

There is no financial conflict of interest regarding studies from my laboratory presented in this paper.

\section{REFERENCES}

[1] Wiesel TN, Hubel DH. Effects of visual deprivation on morphology and physiology of cells in the cat's lateral geniculate body. J Neurophysiol. 1963;26:978-93.

[2] Harris WA. Neural activity and development. Annu Rev Physiol. 1981;43:698-710.

[3] Shaw C, Cynander M. Disruption of cortical activity prevents ocular dominance changes in monocularly deprived kittens. Nature. 1984;308:731-4.

[4] Reiter HO, Waitzman DM, Stryker MP. Cortical activity blockade prevents ocular dominance plasticity in the kitten visual cortex. Exp. Brain Res. 1986;65:182-8.

[5] Shatz CJ, Stryker MP. Prenatal tetrodotoxin infusion blocks segregation of retinogeniculate afferents. Science. 1988;242:87-9.

[6] Parks TN. Afferent influence on the development of the brainstem auditory nuclei of the chicken: Otocyst ablation. J Comp Neurol. 1979;183:665-78.

[7] Meisami E, Monsavi R. Lasting effects of early olfactory deprivation on the growth, DNA, RNA and protein content, and Na-K-ATPase activity of the olfactory bulb. Dev Brain Res. 1981;2:217-29.

[8] Woolsey TA, Wann JR. Areal changes in mouse cortical barrels following vibrissal damage at different postnatal ages. J Comp Neurol. 1976;170:53-66.

[9] Hendry SAC, Jones EG. Reduction in number of immunostained GABAergic neurons in deprived-eye dominance columns of monkey area 17. Nature. 1986;320:750-3.

[10] Simons DJ, Land PW. Early experience of tactile stimulation influences organization of somatic sensory cortex. Nature. 1987;326:694-97.

[11] Hendry SAC, Jones EG. Activity-dependent regulation of GABA expression in the visual cortex of adult monkeys. Neuron. 1988;1:701-12.

[12] Benevento LA, Bakkum BW, Cohen RS. Gammaaminobutyric acid and somatostatin immunoreactivity in the visual cortex of normal and dark reared rats. Brain Res. 1995;689:172-82.

[13] Michaeva KD, Beaulieu C. An anatomical substrate for experience dependent plasticity of the rat barrel cortex. Proc Natl Acad Sci USA. 1995;92:11834-8.

[14] Janka Z, Jones DG. Junctions in rat neocortical explants cultured in TTX-, and $\mathrm{Mg}^{2+}$-environments. Brain Res Bull. 1982;47:289-92.

[15] Van Huizen F, Romijn HJ, Habets AMMC. Synaptogenesis in rat cerebral cortex cultures is affected during chronic blockade of bioelectric activity by tetrodotoxin. Dev Brain Res. 1985;19:67-80.

[16] Ramakers GJA, Corner MA, Habets AMMC. Development in the absence of spontaneous bioelectric activity results in increased stereotype burst firing in cultures of dissociated cerebral cortex. Exp Brain Res. 1990;79:157-66.

[17] Baker RE, Ruijter JM. Chronic blockade of bioelectric activity in neonatal rat neocortex in vitro: Physiological effects. Int J Dev Neurosci. 1991;9:321-9.

[18] Ruijter JM, Baker RE, DeJong BM, Romijn HJ. Chronic blockade of bioelectric activity in neonatal rat cortex grown in vitro: Morphological effects. Int J Dev Neurosci. 1991;9:331-8.

[19] Furshpan EJ. Seizure-like activity in cell culture. Epilepsy Res. 1991;10:24-32.

[20] Corner MA, Ramakers GJA. Spontaneous firing as an epigenetic factor in brain development - Physiological consequences of chronic tetrodotoxin and picrotoxin 
exposure on cultured rat neocortex neurons. Dev Brain Res. 1992;65:57-64.

[21] Van Huizen F, Romijn HJ, van den Hooff P, Habets AMMC. Picrotoxin induced disinhibition of spontaneous bioelectric activity accelerates synaptogenesis in rat cerebral cortex cultures. Exp Neurol. 1987;97:280-8.

[22] Nelson PG, Fields RD, Yu C, Neale EA. Mechanisms involved with activity-dependent synapse formation in mammalian central nervous system cultures. J Neurobiol. 1990;21:138-56.

[23] Ramakers GJA, Corner MA, Habets AMMC. Abnormalities in the spontaneous firing patterns of cultured rat neocortical neurons after chronic exposure to picrotoxin during development in vitro. Brain Res Bull. 1991;26:429-32.

[24] Thoenen H. Neurotrophins and neuronal plasticity. Science. 1995;270:593-8.

[25] Bonhoeffer T. Neurotrophins and activity-dependent development of the neocortex. Curr Opinion Neurobiol. 1996;6:119-26.

[26] Marty S, Berzaghi MP, Berninger B. Neurotrophins and activity dependent plasticity of cortical neurons. Trends Neurosci. 1997;20:198-202.

[27] Lindsay RM. Neurotrophins and receptors. Progr Brain Res. 1994;103:3-14.

[28] Bothwell M. Functional interactions of neurotrophins and neurotrophin receptors. Annu Rev Neurosci. 1995;18:22353.

[29] Lewin GR, Barde Y-A. Physiology of the neurotrophins. Annu Rev Neurosci. 1996;19:289-317.

[30] Rutherford LC, DeWan A, Lauer HM, Turrigiano GG. Brain-derived neurotrophic factor mediates the activitydependent regulation of inhibition in neocortical cultures. J Neurosci. 1997;17:4527-35.

[31] Seil FJ. TrkB receptor signaling and activity-dependent inhibitory synaptogenesis. Histol. Histopathol. 2003;18:635-46.

[32] Seil FJ. The changeable nervous system: Studies on neuroplasticity in cerebellar cultures. Neurosci. Biobehav Rev. 2014;45:212-32.

[33] Eccles JS, Ito M, Szentàgothai J. The Cerebellum as a Neuronal Machine. Springer, New York. 1967.

[34] Palay SL, Chan-Palay V. Cerebellar Cortex. Springer, New York. 1974.

[35] Seil FJ. Neuronal groups and fiber patterns in cerebellar tissue cultures. Brain Res. 1972;42:33-51.

[36] Leiman AL, Seil FJ. Spontaneous and evoked bioelectric activity in organized cerebellar tissue cultures. Exp Neurol. 1973;40:748-59.

[37] Seil FJ, Leiman AL. Development of spontaneous and evoked electrical activity of cerebellum in tissue culture. Exp Neurol. 1979;64:61-75.

[38] Herndon RM, Seil FJ, Seidman C. Synaptogenesis in mouse cerebellum: A comparative in vivo and tissue culture study. Neuroscience. 1981;6:2587-98.

[39] Blank NK, Seil FJ. Mature Purkinje cells in cerebellar tissue cultures. J Comp Neurol. 1982;208:169-76.

[40] Bornstein MB, Murray MR. Serial observations on patterns of growth, myelin formation, maintenance and degeneration in cultures of new-born rat and kitten cerebellum. J Biochem Biophys Cytol. 1958;4:499-504.

[41] Seil FJ. Cerebellum in tissue culture. In: Schneider DM, editor. Reviews of Neuroscience, New York: Raven Press; 1979;4:105-77.

[42] Seil FJ, Drake-Baumann R, Leiman AL, Herndon RM, Tiekotter KL. Morphological correlates of altered neuronal activity in organotypic cultures chronically exposed to antiGABA agents. Dev Brain Res. 1994;77:123-32.

[43] Seil FJ, Drake-Baumann R. Reduced cortical inhibitory synaptogenesis in organotypic cultures developing in the absence of neuronal activity. J Comp Neurol. 1994;342:36677.

[44] Crain SM, Bornstein MB, Peterson ER. Maturation of cultured embryonic tissue during chronic exposure to agents which prevent bioelectric activity. Brain Res. 1968;8:36372.

[45] Model PG, Bornstein MB, Crain SM, Pappas, GD. An electron microscopic study of the development of synapses in cultured fetal mouse cerebrum continuously exposed to xylocaine. J Cell Biol. 1971;49:362-71.

[46] Ernfors P, Merlio J-P, Persson H. Cells expressing mRNA for neurotrophins and their receptors during embryonic rat development. Eur J Neurosci. 1992;4:1140-58.

[47] Lärkfors L, Lindsay RM, Alderson RF. Characterization of the responses of Purkinje cells to neurotrophin treatment. J Neurochem. 1996;66:1362-73.

[48] Seil FJ. BDNF and NT-4, but not NT-3, promote development of inhibitory synapses in the absence of neuronal activity. Brain Res. 1999;818:561-4.

[49] Seil FJ, Drake-Baumann R. TrkB receptor ligands promote activity-dependent inhibitory synaptogenesis. J Neurosci. 2000;20:5367-73.

[50] Zafra F, Castrén H, Thoenen H, Lindholm D. Interplay between glutamate and $\gamma$-aminobutyric acid transmitter systems in the physiological regulation of brain-derived neurotrophic factor and nerve growth factor synthesis in hippocampal neurons. Proc Natl Acad Sci USA. 1991;88:10037-41.

[51] Lindholm D, Castrén E, Berzaghi M, Blöchl A, Thoenen $\mathrm{H}$. Activity dependent and hormonal regulation of neurotrophin mRNA levels in the brain - implications for neuroplasticity. J Neurobiol. 1994;25:1362-72.

[52] Clary DO, Weskamp G, Austin LR, Reichardt LF. TrkA cross-linking mimics neuronal responses to nerve growth factor. Mol Biol Cell. 1994;5:549-63.

[53] Lucidi-Phillipi CA, Clary DO, Reichardt LF, Gage FH. TrkA activation is sufficient to rescue axotomized cholinergic neurons. Neuron. 1996;16:653-63.

[54] Pizzorusso T, Berardi N, Rossi FM, Viegi A, Venstrom K, Reichardt LF, Maffei L. TrkA activation in the rat visual cortex by antirat TrkA IgG prevents the effect of monocular deprivation. Eur J Neurosci. 1999;11:204-12.

[55] Gerlai R. Eph receptors and neuroplasticity. Nature Neurosci Rev. 2001;2:205-8.

[56] Seil FJ. Signaling for activity-dependent synaptogenesis via the TrkB receptor. Exp Neurol. 2001;171:422-4.

[57] Sleiman SF, Chao MV. Downstream consequences of exercise through the action of BDNF. Brain Plasticity. 2015; $1: 143-8$

[58] Nudo RJ, Wise BM, SiFuentes F, Milikan GW. Neural substrates for the effect of rehabilitative training on motor recovery after ischemic infarct. Science. 1996;272: 1791-4.

[59] Dimyan MA, Cohen LC. Neuroplasticity in the context of rehabilitation after stroke. Nat Rev Neurol. 2011;7: 76-85.

[60] Schäbitz W-R, Berger C, Kollmar R, Seitz M, Tanay E, Kiesling M, Schwab S, Sommer C. Effect of brain-derived neurotrophic factor treatment and forced arm use on functional motor recovery after small cortical ischemia. Stroke. 2004;35:992-7. 
[61] Ploughman M, Windle V, MacLellan CL, White N, Doré JJ, Corbett D. Brain-derived neurotrophic factor contributes to recovery of skilled reaching after focal ischemia in rats. Stroke. 2009;40:1490-5.
[62] Clarkson AM, Overman JJ, Zhong S, Mueller R, Lynch G, Carmichael ST. AMPA receptor-induced local brain-derived neurotrophic factor signaling mediates motor recovery after stroke. J Neurosci. 2011;31:3766-75. 